The research program of the Center for Economic Studies (CES) produces a wide range of theoretical and empirical economic analyses that serve to improve the statistical programs of the U.S. Bureau of the Census. Many of these analyses take the form of CES research papers. The papers are intended to make the results of CES research available to economists and other interested parties in order to encourage discussion and obtain suggestions for revision before publication. The papers are unofficial and have not undergone the review accorded official Census Bureau publications. The opinions and conclusions expressed in the papers are those of the authors and do not necessarily represent those of the U.S. Bureau of the Census. Republication in whole or part must be cleared with the authors.

\title{
THE DYNAMICS OF MARKET STRUCTURE AND MARKET SIZE IN TWO HEALTH SERVICES INDUSTRIES
}

Timothy Dunne* Federal Reserve Bank of Cleveland

\author{
Shawn Klimek * \\ U.S. Bureau of the Census
}

Mark J. Roberts *

The Pennsylvania State University and NBER

\author{
and \\ Yi Xu* \\ New York University
}

CES 07-26 October, 2007

All papers are screened to ensure that they do not disclose confidential information. Persons who wish to obtain a copy of the paper, submit comments about the paper, or obtain general information about the series should contact Sang V. Nguyen, Editor, Discussion Papers, Center for Economic Studies, Bureau of the Census, 4600 Silver Hill Road, 2K132F, Washington, DC 20233, (301-763-1882) or INTERNET address sang.v.nquyen@censu.s.gov. 


\begin{abstract}
The relationship between the size of a market and the competitiveness of the market has been of long-standing interest to IO economists. Empirical studies have used the relationship between the size of the geographic market and both the number of firms in the market and the average sales of the firms to draw inferences about the degree of competition in the market. This paper extends this framework to incorporate the analysis of entry and exit flows. A key implication of recent entry and exit models is that current market structure will likely depend upon history of past participation. The paper explores these issues empirically by examining producer dynamics for two health service industries, dentistry and chiropractic services. We find that the number of potential entrants and past number of incumbent firms are correlated with current market structure. The empirical results also show that as market size increases the number of firms rises less than proportionately, firm size increases, and average productivity increases. However, the magnitude of the correlations are sensitive to the inclusion of the market history variables.

* This paper reports the results of research and analysis undertaken by the U.S. Census Bureau staff. It has undergone a Census Bureau review more limited in scope than that given to official Census Bureau publications. This report is released to inform interested parties of ongoing research and to encourage discussion of work in progress. The research results and conclusions expressed are those of the authors and do not necessarily reflect the views of the Census Bureau. This paper has been screened to ensure that no confidential data are revealed.
\end{abstract}




\section{Introduction}

The relationship between the size of a market and the structure of production - the number of firms, their relative size, and the magnitude of entry and exit flows - is determined by a large set of underlying structural factors including the competitiveness of the market, the magnitude of sunk entry costs, the importance of economies of scale in production, the relationship between production cost and product quality, and the magnitude of cost heterogeneity among producers.

A number of empirical studies in industrial organization have used products that are sold in small geographic markets to study the cross-sectional relationship between market size and market structure. Studies of the relationships between market size, generally measured as population, and the number of firms in the market (Bresnahan and Reiss $(1989,1991)$, Asplund and Sandin, (1999), and Berry and Waldfogel,(2003)), the average sales of the firms (Campbell and Hopenhayn, (2005)), and the magnitude of cost heterogeneity (Syverson, (2004)) have been used to indirectly draw inferences about these underlying structural factors, particularly the degree of competition in the market. ${ }^{1}$ A common factor in virtually all of the empirical literature is that they are based on a two-period long-run equilibrium model which explains the number and size of firms as a function of market size. Each paper tends to focus on the cross-sectional correlation between one aspect of market structure and market size.

The data and theoretical framework used in these studies are not well suited to examining entry and exit flows or to identify the role that sunk entry costs might play in the evolution of market structure. More recently, explicit dynamic models have been developed that generate a relationship between market size and firm turnover (Asplund and Nocke (2006) and Pakes, Ostrovsky and Berry, (forthcoming)). These dynamic models distinguish incumbent producers

\footnotetext{
${ }^{1}$ Berry and Reiss (2006) summarize this literature and discuss the modeling assumptions needed to separately identify the degree of competition in the market from other structural factors, particularly the magnitude of fixed costs.
} 
from potential entrants and recognize that, when sunk entry costs are present, the value functions of the two groups are different. This makes an incumbent's decision to remain in operation or exit different from the decision of a potential entrant and leads to a framework in which market history, specifically past market structure, is a determinant of current market structure. With the exception of Bresnahan and Reiss (1994), the role of past market structure has not been examined in the empirical market structure literature.

In this paper we utilize data from the U.S. Census of Service Industries to study the evolution of market structure in two health services industries, dentists and chiropractors. We use data for the period 1977-2002 to document a set of empirical facts linking the number of firms, and the flows of entering and exiting firms, to both market size and past market structure. It is particularly interesting to examine the market structures of health service industries because the market demand is closely tied to population, so that market size should be important, and there are substantial sunk costs involved in establishing a practice, so that the history of market structure should also be a significant determinant. The empirical results indicate that past market structure, specifically the number of firms in the market in previous periods and the number of potential entrants to the market, play an important role in determining the flow of entering and exiting firms. Together these imply that market history is a significant determinant of current market structure, as the dynamic models of entry and exit imply. The inclusion of lagged market structure also leads to a large reduction in the role of current market size and thus would have a significant impact on conclusions about market competition that are based on the two-period long-run equilibrium models.

In the next section of the paper we review the theoretical arguments and empirical findings from the two-period long-run models and then contrast them with an explicitly dynamic model of entry and exit. The third section summarizes the market-level data we utilize, focusing 
on the number of dentists and chiropractors in geographic markets in the U.S. The fourth section summarizes the empirical model of entry and exit we estimate and the fifth section presents the empirical results.

\section{Models of Entry, Exit, and Market Structure}

\subsection{The Number of Firms}

The primary model that has guided empirical work on entry and exit is first outlined in a series of papers by Bresnahan and Reiss $(1989,1991)$ and Sutton (1991). There are two time periods. In the first period, a large group of ex ante identical potential entrants make a decision to enter the market after paying a fixed cost to enter. In the second period, production occurs and profits are realized. The second period profits are determined by the nature of competition in the market, Cournot vs. Bertrand vs. collusion for example, and the number of firms that entered in the first stage. In equilibrium, the number of firms that enter will be determined by a zero net profit condition; entry will occur until the second stage profits fall below the fixed entry cost. What Bresnahan and Reiss and Sutton show is that the zero profit condition can be used to guide empirical work explaining the number of firms in the market.

In the simplest version of this framework, all firms in a market are identical. Let $Z$ represent a set of exogenous market-level variables that determine demand and cost conditions in a market such as the number of consumers and factor prices. Let $V(N, Z)$ be the profits earned by each firm in a market when there are $N$ producers. If $\phi$ is the common fixed cost of entry then the equilibrium number of firms $N^{*}$ can described by two entry conditions:

$$
V\left(N^{*}, Z\right) \geq \phi \text { and } V\left(N^{*}+1, Z\right)<\phi \text {. }
$$

In a market with $N^{*}$ firms, profits for each will cover the fixed cost, while in a market with $N^{*}+1$ firms they will not. Almost all empirical applications of this framework have used data on $N$ and 
$Z$ from a cross-section of geographic markets to estimate parameters of the profit function, particularly the effect of a change in the number of firms on profits, and the fixed cost. If we assume that the fixed cost in each market is an independent draw from a common normal distribution for $\phi$, then the equilibrium entry conditions imply an ordered probit model for the number of firms with $Z$ and any variables that shift the distribution of $\phi$ as the explanatory variables in the model. Berry and Reiss (2006) and Berry and Tamer (2006) discuss the assumptions on $V$ and $\phi$ that are necessary to estimate the parameters of the profit function and fixed cost distribution in this homogenous firm framework. In general, they show that if only $N$ and $Z$ are observed and profit data is not observed, then distributional assumptions on $F$ and functional form restrictions on $V$ are needed to estimate the profit and fixed cost parameters. A particularly interesting special case, which has played a large role in the empirical studies, is where the profit function can be written as the product of a per-customer profit function $V^{C}(N, Z)$ and the number of customers $S: V(N, Z)=V^{C}(N, Z) S$. In this case, $S$ is interpreted as a measure of market size and so cross-sectional variation in market size generates cross-sectional variation in firm profits. In this case, the empirical relationship between $N$ and $S$ can be used to draw inferences about the competitive effect of entry, that is, the effect of $N$ on the profit function $V$, without using profit data. If this competitive effect is present in a market then entry of additional firms into a market compresses the average markup of all firms in operation, lowering $V$. At the entry stage the market size needed to support an additional firm will be larger than if this competitive effect is absent. Alternatively, larger markets will support more firms but will also have a larger average market size per firm $(S / N)$.

This competitive effect can show up in the market size correlations in other ways as well. Campbell and Hopenhayn (2005) develop the implications of increased market size on the average size of firms in the market. If larger markets are more competitive and hence have lower 
markups, then average firm size will be larger because the firms must sell more output to cover their fixed costs. They find evidence of this correlation in 13 U.S. retail industries. Syverson (2004) incorporates firm heterogeneity into the two-period framework. ${ }^{2}$ Firms are allowed to differ in marginal costs and he shows that competitive effects can be reflected in the distribution of costs or productivities in a market. In his case a homogeneous product is produced by plants with different marginal cost. Product differentiation is introduced through the spatial dispersion of customers and the presence of high transport costs. Together these make each producer’s output an imperfect substitute for the output of others. An increase in demand density, the number of customers per unit of area, leads to an increase in producer density which, in turn, lowers prices and profit margins for all plants in the market and raises the failure rate of high-cost producers. As a result, more densely populated markets will be more efficient, having a higher proportion of low-cost producers. He finds empirical evidence of higher efficiency in large markets for the U.S. ready-mix concrete industry.

Asplund and Nocke (2006) move beyond the two-period framework and develop a dynamic equilibrium model in which market size has implications for the rate of firm turnover. The underlying competitive mechanism is similar to these other papers: an increase in competition as market size increases results in large markets having more firms with higher perfirm sales but lower price-cost margins. This results in the marginal surviving firm being more productive in larger markets, which is reflected in higher turnover and a younger age distribution

\footnotetext{
${ }^{2}$ A number of other papers have incorporated firm heterogeneity in the two-period framework. In his study of airline markets, Berry (1992) allows for differences in fixed costs across firms and models the number of firms as a function of market and firm characteristics. He finds that average firm profits are negatively affected by an increase in the number of producers. Mazzeo (2002) and Seim (2002) allow for different degrees of product differentiation across firms within the same market. Mazzeo models the number of high-quality and low-quality firms in a market and finds significant own and cross-effects of the number of firms of each type on the average profits of each type. Seim allows firms to differ in their geographic location within the market and studies the location decision of new firms. She finds that increasing distance between firms insulates them from the competitive effects.
} 
of firms in larger markets. They find empirical evidence supporting this for Swedish hair salons.

\subsection{Entry and Exit Flows}

With the exception of Asplund and Nocke (2006), the empirical literature summarized in section 2.1 focuses on long-run differences in the number of firms, not on entry and exit flows directly. While the underlying two-period framework can allow for producer heterogeneity in fixed costs or profits, which leads one firm to choose to be in the market while another chooses to be out, it does not provide any insights into what determines the magniture of entry and exit flows. One aspect that is generally missed in the two-period model is the distinction between the role of fixed costs that all producers pay and the role of sunk entry costs that are only paid by firms at the time of entry. ${ }^{3}$ This leads to a difference in the objective function and participation decision of incumbent and potential entrant firms. Incumbents compare the expected sum of discounted future profits with the scrap value they would earn by liquidating the firm. In contrast, potential entrants compare the discounted future payoff from entering with the sunk entry cost they must incur. This distinction has important implications for the way that the number of firms responds to exogenous factors that change profits.

Sunk entry costs combined with uncertainty about future market conditions, gives rise to hysteresis in market structure (Dixit and Pindyck (1994)). For example, suppose there is an exogenous increase in market size that raises firm profits sufficiently to induce potential entrants to pay the sunk cost and enter the market. If the market size and profits then return to their initial levels those new firms may find it profitable to remain in operation rather than exit. The number of firms thus responds asymmetrically to changes in market size. Equivalently, the history of market structure, and not just current and future profit determinants, matters in explaining the

\footnotetext{
3 Berry (1992) allows the fixed cost of an airline on a route to depend on whether or not the airline had a presence at the endpoint cities which distinguishes incumbents from potential entrants in the endpoint markets.
} 
current number of firms.

The level of the sunk entry cost also affects the magnitude of entry and exit flows in the market. Using a competitive, industry-equilibrium model, Hopenhayn (1992) shows that an increase in the sunk entry cost will reduce the flow of entering firms in the market but also reduce the flow of exiting firms. The higher entry cost acts to insulate incumbent firms from the pressure of entry and allows more inefficient incumbents to survive. Thus the entry cost is an important structural element affecting entry and exit flows and the degree of market efficiency.

Recently, fully dynamic models that recognize the distinction between incumbent and potential entrant firms have been developed that can explain differences in entry and exit flows across markets and/or industries. Pesendorfer and Schmidt-Dengler (2003), Aguirregabiria and Mira (2007), Das, Roberts, and Tybout (2007), Collard-Wexler (2006), and Ryan (2006) all use micro data on firm participation patterns in a market to estimate structural models of entry and exit, including the sunk costs of entry.

Pakes, Ostrovsky, and Berry (forthcoming) develop a dynamic model that is very useful as a framework for studying the flows of entering and exiting firms in market-level data. This leads to a formulation for regressions of entry, exit, and the number of firms that can be distinguished from the two-period models but estimated with the same type of cross-sectional or panel marketlevel data. We will briefly summarize this model and then use it to specify regression models of entry and exit.

The model assumes that in a market each firm earns identical profits given by $\pi(N, Z)$ where $N$ is the number of firms that operate in the period and $Z$ is a set of exogenous cost and demand shifters. The state variables $Z$ evolve exogenously over time as market conditions change while $N$ evolves endogenously as firms make optimal entry and exit decisions. In each period an incumbent faces a choice of remaining in the market in the next period or exiting. If firm $i$ 
chooses to exit they earn a scrap value $\phi_{i}$, which is modeled as an independent draw from an underlying distribution $F^{\phi}(\cdot / \sigma)$ where $\sigma$ is a parameter that characterizes the distribution. The distribution is common for all firms and time periods. If they remain in they earn expected profits $V C(N, Z, \sigma)$ which is the expectation of the firm value in the next period and is identical for all incumbents in the market. ${ }^{4}$ Incumbent firm $i$ chooses to remain in the market if $V C(N, Z, \sigma) \geq \phi_{i}$. Similarly each potential entrant faces a decision to enter at the start of the next period. The payoff from entering is represented as $V E(N, Z, \sigma)$ and is the same for all potential entrants in the market. Each potential entrant differs in their entry cost $\kappa_{i}$ which is modeled as an independent draw from a common distribution $F^{\kappa}(\cdot / \beta)$, where the parameter $\beta$ characterizes the entry cost distribution. The firm enters the market if $V E(N, Z, \sigma,) \geq \kappa_{i}$.

This framework differs from the two-period model outlined above in several important ways. First, incumbents and potential entrants differ. The latter must pay an entry cost but also the expected firm value from continuing in production $V C$ is different than the expected firm value from entering $V E .^{5}$ Second, firm-level heterogeneity, which is absent from the simplest two period models, is introduced through the random scrap value and entry cost. This model is capable of generating simultaneous flows of entering and exiting firms into the same market, something that simpler models with homogenous firms cannot do.

This model results in simple expressions for the probability of entry and exit. The probability an incumbent firm exits from a market with current state $N, Z$ is given by:

$$
P_{X}(N, Z, \sigma)=\operatorname{Prob}(V C(N, Z, \sigma) \leq \phi)=1-F^{\phi}(V C(N, Z, \sigma) / \sigma)
$$

\footnotetext{
4 The expectation is over the future values of the state variables $N, Z$ and the scrap value $\phi$.

${ }^{5} \operatorname{VE}(N, Z, \sigma)$ and $\operatorname{VC}(N, Z, \sigma)$ are not identical. The former is the expected firm value from the perspective of a firm which chooses to enter, and thus knows there is at least one entering firm in the market. The latter is the expected firm value from the perspective of an incumbent that chooses to remain in the market and thus knows there is at least one survivor. Each group thus has a different expectation for the number of firms $N$ in the market in future periods.
} 
Since this probability is the same for all incumbents in the market, the numbering of exiting firms $N X$ is a binomial random variable with the parameters $P_{X}$ and $N$, where the number of incumbent firms is the number of trials in the process.

Similarly, the number of entering firms is also a binomial random variable. The probability of one firm entering the market with current state $(N, Z)$ is:

$$
P_{E}(N, Z, \sigma, \beta)=\operatorname{Prob}(V E(N, Z, \sigma) \geq \kappa)=F^{\kappa}(\operatorname{VE}(N, Z, \sigma) / \beta)
$$

This probability is the same for all potential entrants to the market so the number of entering firms $N E$ is a binomial random variable with parameters $P_{E}$ and $N P E$, where the latter is the number of potential entrants to the market.

To summarize, the theoretical model provides a basis for a statistical model of the number of entering and exiting firms in a market. The entry and exit flows ( $N X$ and $N E$ ) over a time period are a function of exogenous state variables $Z$ that affect profits in the beginning time period (and determine values in future time periods) and the number of firms $N$ and number of potential entrants NPE at the beginning of the period. In section 4 we estimate equations for the entry and exit flows based on this specificiation.

\section{Measuring Entry and Exit for Dentists and Chiropractors using Census Data}

The data used in the analysis come from US Census Bureau's Longitudinal Business Database (LBD). The LBD contains establishment-level data on all employers in the United States from 1976 through 2005. The database allows for the measurement of establishment and firm dynamics across almost all sectors of the U.S. economy. ${ }^{6}$ While prior research focused primarily on the analysis of firm dynamics in the manufacturing sector, the recent development of non-manufacturing data allows for the analysis of producer turnover across a much wider range of industries.

\footnotetext{
${ }^{6}$ Jarmin and Miranda (2002) discuss the measurement issues involved in constructing the LBD.
} 
In this paper, we examine entry and exit in two health services industries, dentists (NAICS 621210) and chiropractors (SIC 621310), where little is known about the patterns of firm dynamics. Dental and chiropractic services are dominated by small, single location firms typically owned by the practicing doctor(s). While Census data collection is establishment based, for these industries virtually all firms are single establishment practices, particularly in the small markets we will utilize, and we use the terms interchangeably in this paper. These firms provide their services in relatively small markets with the demand for services tied closely to local market conditions, particularly population. The technologies are also similar across dental and chiropractic establishments in that they combine office staff, specialized capital equipment, and doctors' time to provide health services. Our analysis augments the LBD with revenue, payroll, employment, and geographic coding data from the Census of Services limiting the data set to the

Census years of 1977, 1982, 1987, 1992, 1997 and 2002. The remainder of this section discusses market definitions, the measurement of entry and exit, and the construction of market-level variables.

\subsection{Defining Markets and Market Participation}

Throughout this paper, we focus our attention on small and isolated geographic areas so that we can better define the market served, similar in spirit to the approach taken by Bresnahan and Reiss (1989, 1991). We first identified a set cities and towns that are geographically distinct from large population centers. From this list of potential markets, we kept only those locales with populations of less than 50,000 and consistent place coding in the Census of Services over time. Our markets include 754 incorporated places that vary in population from 2,500 to 50,000 people, and are, on average, larger than the locales used by Bresnahan and Reiss. All 754 geographic areas had a dental practice present in at least one year; but because they require a larger 
population to sustain a practice, only 689 of the geographic areas had a chiropractic practice present.

The measure of entry used in this paper is the entry of an establishment into one of these geographic markets. An entrant in a market is defined as an establishment that is not producing in market $m$ in period $t$ but is producing in market $m$ in period $t+5$ (the next Census year). ${ }^{7}$ An exit is similarly defined as an establishment that is in market $m$ in period $t$ and is not in that market in period $t+5$. For each market $m$ and in each time interval, we construct the number of entering establishments $\left(N E_{m t}\right)$, the number of exiting establishments $\left(N X_{m t}\right)$ and the number of establishments $\left(N_{m t}\right)$. The data allow us to measure entry and exit for five time intervals (19771982, 1982-1987, 1987-1992, 1992-1997 and 1997-2002) and for 754 geographic markets yielding a data set of 3770 market-time observations.

To give a sense of how entry and exit varies across the markets in our data, Figures 1-3 show the cumulative density of the number of establishments, number of entrants, and number of exiting establishments. The distribution for dentists is shifted to the right in all three panels indicating that the number of offices per market, as well as the number of entering and exiting producers, is larger for dentists compared to chiropractors. The graph also shows that many of our markets have a relatively small number of producers. In fact, the majority of markets support less than three chiropractors and less than eight dentists. One difference between these two industries is that the number of chiropractic offices grew rapidly over the period of analysis while dentists experienced slower growth. The average number of dentists offices in our markets grew

\footnotetext{
${ }^{7}$ Almost all entering and exiting establishments in these data represent establishment birth and deaths. However, some establishments in the data switch geographic codes over time and such geographic market switching can generate entry and exit under our definitions. We restrict certain types of these geographic market switching. In particular, establishments within a county will sometimes switch between a "rest of county" place code and a place code identifying a city. We do not allow these within-county changes in geographic coding to generate entry and exit. In these cases, we fix the place code to the code that identifies the city and the treat the establishment as continuing in that location .
} 
by $16.5 \%$ whereas the growth in chiropractors offices increased by $142.5 \%$. Still, the number of chiropractic offices was only $31.5 \%$ of the number of dentists offices by the end of the sample period.

\subsection{Market Level Variables}

Throughout the analysis, three variables are used to characterize market structure - the number of establishments (discussed above), the average size, measured as real revenue, of producers, and the average labor productivity of producers. We use the data from the Census of Services to measure the average revenue of practices in a market and deflate this by the Consumer Price Index (CPI). Average labor productivity for a market is similarly constructed by taking real revenue of a practice and dividing it by the establishment's total employment and then averaging across all producers in the market. ${ }^{8}$

Our empirical models use three variables to capture differences in demand and cost conditions across markets. To control for demand differences, we include the population of the geographic market and per-capita income. Population in a market $\left(S_{m}\right)$ has been the main proxy used to measure market size in most previous studies of entry. Population figures on incorporated places are obtained from the Census Bureau's series on population estimates, but we interpolate the data for our places in some earlier years from the Decennial Census when population estimates are unavailable. The real per-capita-income variable $\left(P C I_{m t}\right)$ from the Bureau of Economic Analysis is measured at the county level and deflated by the CPI. To control for cost differences, we construct the average real wage $\left(W_{m t}\right)$ paid to workers employed in the health practitioners' offices (NAICS 62111-621399) in the county, again deflating by the national CPI.

\footnotetext{
${ }^{8}$ In these industries, dentists and chiropractors are the main generators of revenue but if the legal form of organization is a sole proprietor or a partnership these owner-practitioners will not be counted in employment. To account for this omission, we modify total employment at an establishment for sole proprietors by adding one employee and for partnerships by adding two employees.
} 
Because we do not have local price deflators, variation in the wage and income variables will also reflect price-level differences across geographic markets, which are likely to be important in these data.

The dynamic entry model from section 2.2 implies that the history of market structure matters in determining current market structure. Two variables are used to control for history in our empirical models - the lagged or beginning period number of firms in a market and the lagged or beginning period number of potential entrants $\left(N P E_{m t}\right)$ that were present in the market. The number of potential entrants into a geographic market in a time-period is equal to the maximum number of different establishments that appear in the market over time minus the current number of establishments in operation. The rationale behind this definition is that in each geographic market we observe all potential entrants being active at some point in time. In each time period the pool of potential entrants is the set of establishments that are not currently active.

A main focus of prior work has been an examination of how the number of firms in a market varies with market size. Figure 4 graphs this relationship for dentists and chiropractors using a locally weighted regression. ${ }^{9} \quad$ Larger markets support a larger number of practices in both industries and, as noted above, the number of dental practices per capita is significantly greater than chiropractic practices per capita. Our largest markets support in excess of 20 dentists per market while for chiropractors the largest markets only support about five producers. Since chiropractic offices also have lower revenue, on average, than dentist offices, the data reflect the fact that per-capita demand for chiropractic services is much less than dental services. Figures 5 and 6 graph the relationship between market population and the number of entering and exiting

\footnotetext{
${ }^{9}$ Figures 1 through 9 are produced using STATA's lowess command with a bandwidth of .3 and the default weighting procedure. The lowess command estimates a weighted regression at each observation in the data using nearby data points to construct a smoothed value of the dependent variable conditional on the $\mathrm{x}$ variable.
} 
establishments. The same general patterns hold - there are a greater number of entering and exiting dentists per-capita than chiropractors.

\section{Empirical Model of Entry, Exit and Number of Firms}

The dynamic model of section 2.2 implies that the number of entering and exiting firms is a function of the market characteristics that affect current and future profits, the distribution of scrap values and entry costs, and the number of firms and potential entrants that are present. In this section we specify the estimating equations that we will apply to the market level data for dentists and chiropractors.

The theoretical model from section 2.2 specifies the number of entering and exiting firms as binomial random variables. We could specify the probabilities of entry and exit as functions of the observable state variables and unknown parameters and estimate them using maximum likelihood. The estimation of entry probabilities depends critically on the measurement of the number of potential entrants $\left(N P E_{m t}\right)$ and this variable is difficult to measure accurately. Instead we choose to model the mean number of entering and exiting firms directly and use NPE as one explanatory variable. If it is measured poorly it may still be possible to determine if the other state variables are significant determinants of entry flows. Since the entry and exit flows are count variables, we use an extension of the Poisson model. Given the panel of 754 geographic markets for five five-year periods we specify the flows of entering and exiting practices using a negative binomial regression model.

The mean number of exiting plants is a function of the market-level state variables and the number of potential entrants:

$$
\begin{aligned}
& E\left(N X_{m t} / N_{m t-1}, Z_{m t-1,} N P E_{m t-1}\right)= \\
& \exp \left(\beta_{0}+\beta_{1} \log S_{m t-1}+\beta_{2} \log \left(P C I_{m t-1}\right)+\beta_{3} \log W_{m t-1}+\beta_{4} N_{m t-1}+\beta_{5} N P E_{m t-1}+\sum \gamma_{j} D_{m j}\right)
\end{aligned}
$$


where the $D_{m j}$ is a set of four dummy variables to distinguish the five time periods in the data. The variables are all specified at the start of the time period ( $t-1)$ and the number of exits is measured over the time interval $t-1$ to $t$. The negative binomial model generalizes the Poisson model to allow the variance of the distribution to be greater than the mean using the specification:

$$
\operatorname{Var}\left(N X_{m t}\right)=E\left(N X_{m}\right)\left(1+\alpha_{X} E\left(N X_{m t}\right)\right)
$$

This introduces one new parameter $\alpha_{X}$ which is referred to as the overdispersion parameter. The Poisson model is the special case where $\alpha_{X}=0$.

A similar equation is specified for the mean entry flow:

$$
\begin{aligned}
& E\left(N E_{m t} / N_{m t-1}, Z_{m t-1}, N P E_{m t-1}\right)= \\
& \exp \left(\omega_{0}+\omega_{1} \log S_{m t-1}+\omega_{2} \log \left(P C I_{m t-1}\right)+\omega_{3} \log W_{m t-1}+\omega_{4} N_{m t-1}+\omega_{5} N P E_{m t-1}+\sum \delta_{j} D_{m j}\right)
\end{aligned}
$$

where $N E$ is measured over the time interval $t-1$ to $t$. We also allow for overdispersion in the entry model using the specification in equation (5). It is important to recognize that the coefficients in these entry and exit flow regressions are combinations of profit function, sunk cost, and entry cost parameters and these underlying structural parameters are not separately identified.

Combining the entry and exit models also provides a way to describe the number of firms in year $t$ that is consistent with the dynamic model of entry and exit. The number of firms in year $t$ can be written as $N_{m t}=N_{m t-1}+N E_{m t}-N X_{m t}$. Using equations 4 and 6 for $N E$ and $N X$ we can write $N_{m t}$ as a function of the state variables, lagged number of firms, and number of potential entrants:

$$
\begin{aligned}
& E\left(N_{m t} / N_{m t-1}, Z_{m t-1,} N P E_{m t-1}\right)= \\
& \exp \left(\theta_{0}+\theta_{1} \log S_{m t-1}+\theta_{2} \log \left(P C I_{m t-1}\right)+\theta_{3} \log W_{m t-1}+\theta_{4} N_{m t-1}+\theta_{5} N P E_{m t-1}+\sum \eta_{j} D_{m j}\right)
\end{aligned}
$$

Notice that this differs from the specification of $N$ from the two-period models because it depends on lagged $N$ and the number of potential entrants $N P E$. One way to distinguish the two-period and fully dynamic models is by whether these two variables are significant in the model for the number of firms. 
We have estimated both negative binomial and Poisson models and in most cases the amount of overdispersion is relatively small and the coefficient estimates are similar. To simplify discussion, we report only the negative binomial estimates of equations 4-7 in the next section.

\section{Empirical Evidence on Entry, Exit, and Market Structure}

\subsection{Market Structure and Market Size}

Before turning to the regression analysis, we present graphs showing the relationship between market size and market structure for our health service industries. Figures 7-9 depict a set of locally weighted regressions for three variables that describe features of our local markets population per firm $(S / N)$, average revenue per firm, and average firm productivity. These variables, measured in logs, are plotted against $\log S$ in the market. For both industries, average revenue per producer and average labor productivity rise as market size increases though there are some differences in the shape of this relationship between the industries. The rise in average revenue and average labor productivity is greatest for small markets and then flattens out in the larger markets for dentists. However, for chiropractors, the rise in average revenues and labor productivity is most pronounced in mid-size markets. Recall that small markets support very few chiropractors and it is only as markets become mid-sized that we are likely to see multiple chiropractors operating. These increases in average revenue and average labor productivity with market size are consistent with previous empirical research. Campbell and Hopenhayn (2005) finds that average sales per producer rises with market size and Syverson (2004) reports that productivity is higher in larger markets. Both interpret these patterns as consistent with more intense competition in larger markets. The relationship between $\log (S / N)$ and $\log S$ shown in Figure 7 does not provide a uniform picture across the industries. For chiropractors, population per producer rises as market size increases. Again, under the conditions described in Berry and 
Reiss (2006), this pattern is consistent with more competition in larger markets. Alternatively, dentists show a much more muted rise in average population per practice as market size increases suggesting less of a competitive effect.

To control for other variables, Table 1 reports the coefficients from regressions of the number of producers, the average revenue of practices, and average labor productivity in a market on our demand and cost variables. The regression of the number of producers is estimated using the negative binomial count data model for comparability with dynamic model results that are reported below. The log average revenue and log labor productivity models are estimated using ordinary least squares and all models contain year dummies.

The coefficient on market population in the regression for number of establishments $(N)$, is an estimate of the elasticity of $N$ with respect to $S$ and is less than one for both industries, .830 for dentists and .671 for chiropractors. If a competitive effect is present, then the coefficient on market size should be less than one. As observed in Figure 7, chiropractic services appears to have a somewhat stronger competitive effect. One reason for this difference between these industries is that, compared to dentists, a much higher percentage of the markets served by chiropractors have two or fewer producers (see Figure 1). Bresnahan and Reiss found that for their industries the competitive effect was dissipated by the time there were 3 firms in the market. Given the relatively small number of chiropractors operating in many of the markets, it is more likely to find deviations from competitive outcomes in this industry.

The positive relationship between market size and both revenue and labor productivity in these industries can also be interpreted as evidence that a competitive effect of entry is present. The estimated elasticity of average revenue is .108 in dentists and .137 in chiropractic services. Although these elasticities are somewhat greater than those reported by Campbell and Hopenhayn (2005) using similar models, it is consistent with their argument that a competitive effect will 
result in larger firms in larger markets. The larger magnitudes found here may reflect the fact that the markets used in this study are generally smaller and thus more likely to be affected by competitive pressure from entry. Syverson's (2005) model predicts that productivity will be higher in larger markets due to a more intense selection effect and the results are consistent with his findings. The elasticity of average productivity with respect to market size is .053 and .074 in the dentist and chiropractor industries, respectively.

The other demand variable, the log of per-capita income, has a positive elasticity in all three market structure regressions for both industries. These results probably reflect the fact that as incomes rise a greater share of the population uses the services and/or consumers use the service more intensively, resulting in higher market demand, more firms, and higher average revenue. The latter effect could also arise from increased product differentiation and higher prices in wealthier markets. The wage variable has the expected positive sign in the average revenue and productivity regressions, since revenue must rise to cover higher costs, but the positive coefficient in the regressions for the number of producers is unexpected. This suggests that the market wage variable in these regressions not only picks differences in factor costs across locations but also differences in cost-of-living. Markets with higher cost of living will have higher output prices and the net effect of these input and output price changes on profitability is ambiguous. Finally, the alpha parameter estimated from the negative binomial models of the number of producers indicates that overdispersion is present in the model for dentists but not for chiropractors.

\subsection{Entry and Exit}

The regression specifications in Table 1 are motivated by the two-period models of entry summarized in section 2.1. The empirical results for the effect of market size are similar to other empirical studies using this framework and these have generally been interpreted as reflecting a 
competitive effect of entry. The dynamic model of section 2.2 provides a different starting point for the modeling of market structure and indicates that the lagged number of firms and number of potential entrants are determinants of entry and exit flows and thus current market structure. Tables 2 and 3 provide results for models that include these additional explanatory variables.

Table 2 reports the results of negative binomial models using the number of entering and exiting firms as the dependent variables. The most interesting finding in the table is the role played by the controls for the number of firms and the number of potential entrants at the beginning of the period. These regressions are reported in the even-numbered columns in the table. The model in section 2.2 implies that an increase in $N$ should reduce the profit stream from being in the market and so reduce the number of entrants (NE) and increase the number of exits $(N X)$. The model implies an additional effect on exit, holding the profit stream fixed, because an increase in the number of firms making the continuation decision means that the expected number of firms observing a scrap value larger than the value of remaining in the industry, and thus choosing to exit, will rise. Overall, there should be a positive correlations between $N$ and $N X$ and a negative correlation between $N$ and $N E$. The predicted positive correlation between $N$ and $N X$ is observed for both industries and the coefficients, .050 in dentists and .211 in chiropractors, are highly significant. The correlation can reflect either, or both, of the exit linkages in the model and it is not possible using these regressions to identify the separate contribution of each mechanism. The predicted negative relationship between $N$ and $N E$ is not observed in the dentist industry and is observed, but is not statistically significant, for chiropractors. Both coefficients are small when compared with the impact of an increase in the number of potential entrants and this may reflect the second-order impact of an increase in $N$ affecting the number of entrants through its effect on the value of entering.

The dynamic model predicts that an increase in the number of potential entrants NPE 
lowers the discounted value of expected future profits by increasing the expected number of firms operating in the future.. This will lead to less entry and more exit. It has a second impact on the number of entrants. An increase in the number of potential entrants, holding the profit stream fixed, will increase the expected number of firms that draw an entry cost less than the value of entering and thus choose to enter. So the correlation between $N P E$ and $N X$ should be positive while the correlation between $N P E$ and $N E$ is ambiguous. The positive relationship between $N P E$ and $N X$ is observed, the coefficent is .004 for both industries but is only statistically significant for dentists. The estimated relationship between $N P E$ and $N E$ is positive and statistically significant, .043 in dentists and .115 in chiropractors. This suggests that the direct effect of an increase in the size of the pool of potential entrants is more important for the entry flow than the indirect or secondary effect this has on the future profit stream. Overall, the importance of $N$ and NPE as control variables in these regressions provides some support for the dynamic framework.

The second set of results that is of interest in Table 2 concerns the coefficients on the demand and cost variables and how these are affected when lagged market structure variables are included. In models that do not control for $N$ and NPE, reported in the odd-numbered columns of Table 2, the coefficients on the demand and cost variables are all positive indicating that markets with larger population, per-capita income, and wage rates (or price levels) have more producer turnover, that is, both higher entry and exit. Unlike the regressions in Table 1, there is no competition interpretation linked to these results. When $N$ and NPE are included in the regressions the magnitude of each of these coefficients is substantially reduced. For example, comparing the first two columns, the coefficient on the market size variable falls from .839 to .338 when the two variables are included. This is true in all the entry and exit models and suggests that any conclusions we draw based on the relationship between the demand and cost variables and market structure may be sensitive to whether we base the empirical model on the two-period, long-run 
equilibrium model or an explicitly dynamic one.

To explore this last point further we reestimate the market structure models reported in Table 1 but now include the lagged number of firms and potential entrants as additional control variables. These findings are reported in Table 3. First, the lagged number of firms and potential entrants are both significant variables in the regressions for the number of firms, columns 1 and 4 . The importance of these variables is one way to discriminate between the dynamic models which allow for the possibility of hysteresis in market structure, and the two-period models which do not. In addition, for both industries, the other estimated coefficients in these two columns are sensitive to the inclusion of these market history variables. The magnitude of the coefficients on population, per-capita income, and the wage rate all drop markedly in comparison to those reported in Table 1. Of particular interest is the effect on the coefficients of the market size variable, since these have been the focus of most attention in the empirical literature. In the dentist industry, the coefficient on market population drops from .830 in Table 1 to .316 in Table 3 . The corresponding coefficients for chiropractors are .671 and .296. While all the coefficients are significantly different than one and would, if the two-period model was taken literally, imply a competitive effect of entry, the magnitude of the effect is clearly very different between model specifications. This raises questions about how to interpret the estimated relationship between the size of a market and the number of firms.

In contrast to the model of the number of firms, there is little systematic relationship between the lagged market structure variables and either the average revenue or labor productivity variables. The most significant correlations appear between the number of potential entrants and the average revenue and productivity variables for dentists. Still, the results in Table 3 suggest that the lagged market structure variables are determinants of current market structure, particularly the number of firms in the market, as implied by the dynamic model of entry and exit. This only 
serves to further complicate the interpretation of the regression coefficients in this type of model, since they now reflect much more than a possible competitive effect of entry.

\section{Conclusion}

This paper utilizes U.S. Census micro data to study patterns of producer dynamics in two health service industries, dentists and chiropractors. The analysis is guided by studies in the industrial organization literature that quantify the relationship between market size and market structure, where the latter is measured in several ways including the number of firms, the average size of firms, and the level of productivity. The framework is extended to incorporate the analysis of entry and exit flows. Recent models of producer dynamics stress the different decisions faced by incumbent firms and potential entrants. In particular, the existence of a sunk entry cost implies that the decision of an incumbent producer to remain in a market differs in fundamental ways from the decision of a new firm to enter the market. One implication of these recent models is that entry flows, exit flows, and current market structure depend not only on current demand and cost conditions but also on the history of participation decisions.

In order to empirically examine the determinants of entry, exit, and market structure, we use census data for 754 small, geographically isolated markets for dentists and chiropractor services and follow these markets over a 25-year time span. We find a significant role for both the past number of firms and the number of potential entrants as determinants of current market structure and this is consistent with the dynamic model of entry and exit we rely on. Our empirical findings also show that as market size increases the number of firms rises less than proportionally, firm average size increases, and average productivity in the market increases. All of these patterns replicate findings of other studies that have been used to infer that markets become more competitive as they increase in size. However, we find the magnitudes of these correlations, 
particularly for the number of firms, are sensitive to the inclusion of the market history variables and this suggests caution in interpreting the cross-market regressions as revealing much about the competitive structure of the market.

The relationship between the size of a market, the magnitude of barriers to entry including the size of entry costs, and the competitiveness of a market is an issue of long-standing interest in industrial organization. Changes in market size affect firm profitability but also generate flows of entry and exit which also impact profitability. These entry and exit flows are determined, in part, by the magnitude of sunk entry costs, which are very hard to measure and control for in empirical work. The correlations between market size and the number of firms, entry flows, and exit flows will reflect the interaction of these entry barriers, magnitude of competition in the market, and expected future changes in market conditions and profitability. In Dunne, Klimek, Roberts, and Xu (2007) we utilize U.S. Census micro data to estimate an empirical model of entry, exit, and profitability to identify these separate components of market structure and performance. One key to future empirical work in the area of producer dynamics is micro data that can track the evolution of firms and markets over time. Producer data sets that cover a broader range of sectors, countries, and time periods is a crucial component of future research on the sources and impacts of producer dynamics. 


\section{References}

Aguirregabiria, V. and P. Mira (2007), “Sequential Estimation of Dynamic Discrete Games,” Econometrica, Vol. 75, No. 1, pp. 1-53.

Asplund, M. and V. Nocke (2006), “Firm Turnover in Imperfectly Competitive Markets,” The Review of Economic Studies, Vol. 73, No. 2, pp. 295-327.

Asplund, M. and R. Sandin (1999), “The Number of Firms and Production Capacity in Relation to Market Size,” Journal of Industrial Economics, Vol. 47, pp. 69-85.

Berry, S. (1992), "Estimation of a Model of Entry in the Airline Industry,” Econometrica, Vol. 60, No. 4, pp. 889-917.

Berry, S. and P. Reiss (2006), “Empirical Models of Entry and Market Structure, Handbook of Industrial Organization Vol III.

Berry, S. and E. Tamer (2006), “Identification in Models of Oligopoly Entry,” working paper.

Berry, S and J. Waldfogel (2003), “Product Quality and Market Size,” NBER Working Paper 9675.

Bresnahan, T. and P. Reiss (1989), “Do Entry Conditions Vary Across Markets?” Brookings Papers on Economic Activity, Microeconomics Annual, Vol. 1, pp. 833-882.

Bresnahan, T. and P. Reiss (1991), "Entry and Competition in Concentrated Markets,” Journal of Political Economy, Vol. 99, No. 5, pp. 977-1009.

Bresnahan, T. and P. Reiss (1994), "Measuring the Importance of Sunk Costs,” Annales D'Economie et de Statistique, No. 34, pp.181-217.

Campbell, J. and H. Hopenhayn (2005), “Market Size Matters,” Journal of Industrial Economics, Vol. 53, No. 1. pp. 1-25.

Collard-Wexler, A.(2006), "Plant Turnover and Demand Fluctuation in the Ready-Mix Concrete Industry,” Center for Economic Studies Working Paper 06-08, U.S. Census Bureau.

Das, S., M.J. Roberts and J. Tybout (2007), "Market Entry Costs, Producer Heterogeneity, and Export Dynamics,” Econometrica, Vol. 75, No.3, pp.837-873.

Dixit, A. and R. Pindyck (1994), Investment Under Uncertainty, Princeton University Press.

Dunne, T., S.D. Klimek, M.J. Roberts, and Y. Xu (2007), “Entry and Exit in Geographic Markets,” The Pennsylvania State University, Working Paper.

Hopenhayn, H. (1992), “Entry, Exit, and Firm Dynamics in Long Run Equilibrium,” 
Econometrica, Vol. 60, No. 5, pp. 1127-1150.

Jarmin, R. and J. Miranda (2002), “The Longitudinal Business Database,” Center for Economic Studies Working Paper 02-14, U.S. Census Bureau.

Mazzeo, M.J. (2002), “Product Choice and Oligopoly Market Structure,” The Rand Journal of Economics, Vol 33, No. 2, pp. 221-242.

Pakes, A., M. Ostrovsky and S. Berry (forthcoming), "Simple Estimators for Parameters of Discrete Dynamic Games (with Entry/Exit Examples),” The Rand Journal of Economics.

Pesendorfer, M. and P. Schmidt-Dengler (2003), "Identification and Estimation of Dynamic Games,” NBER Working Paper 9726.

Ryan, S. (2006), “The Costs of Environmental Regulation in a Regulated Industry,” MIT Working Paper.

Seim, K. (2006), “An Empirical Model of Firm Entry with Endogenous Product-Type Choices,” The Rand Journal of Economics, Vol37, No. 3, pp.619-642.

Sutton, J. (1991), Sunk Costs and Market Structure, MIT Press.

Syverson, C. (2004), “Market Structure and Productivity: A Concrete Example,” The Journal of Political Economy, Vol. 112, No. 6, pp. 1181-1222. 
Table 1. Results for Market Structure Regressions

\begin{tabular}{|c|c|c|c|c|c|c|}
\hline & \multicolumn{3}{|c|}{ Dentists } & \multicolumn{3}{|c|}{ Chiropractors } \\
\hline & $\begin{array}{l}\text { Number of } \\
\text { Firms* }\end{array}$ & $\begin{array}{l}\text { Log Average } \\
\text { Revenue }\end{array}$ & $\begin{array}{l}\text { Log Labor } \\
\text { Productivity }\end{array}$ & $\begin{array}{l}\text { Number of } \\
\text { Firms* }\end{array}$ & $\begin{array}{l}\text { Log Average } \\
\text { Revenue }\end{array}$ & $\begin{array}{l}\text { Log Labor } \\
\text { Productivity }\end{array}$ \\
\hline Constant & $\begin{array}{l}-5.593 \\
(.472)\end{array}$ & $\begin{array}{l}1.116 \\
(.423)\end{array}$ & $\begin{array}{l}1.825 \\
(.274)\end{array}$ & $\begin{array}{c}-11.265 \\
(.773)\end{array}$ & $\begin{array}{l}-.821 \\
(.695)\end{array}$ & $\begin{array}{l}.733 \\
(.014)\end{array}$ \\
\hline $\begin{array}{l}\text { Log Market } \\
\text { Population }\end{array}$ & $\begin{array}{l}.830 \\
(.013)\end{array}$ & $\begin{array}{l}.108 \\
(.010)\end{array}$ & $\begin{array}{c}.053 \\
(.007)\end{array}$ & $\begin{array}{c}.671 \\
(.020)\end{array}$ & $\begin{array}{l}.137 \\
(.019)\end{array}$ & $\begin{array}{l}.074 \\
(.014)\end{array}$ \\
\hline $\begin{array}{l}\text { Log Per-capita } \\
\text { Income }\end{array}$ & $\begin{array}{l}.416 \\
(.051)\end{array}$ & $\begin{array}{l}.287 \\
(.044)\end{array}$ & $\begin{array}{l}.132 \\
(.028)\end{array}$ & $\begin{array}{l}1.032 \\
(.084)\end{array}$ & $\begin{array}{c}.461 \\
(.078)\end{array}$ & $\begin{array}{l}.230 \\
(.059)\end{array}$ \\
\hline Log Market Wage & $\begin{array}{l}.733 \\
(.048)\end{array}$ & $\begin{array}{l}.413 \\
(.042)\end{array}$ & $\begin{array}{l}.212 \\
(.028)\end{array}$ & $\begin{array}{l}.122 \\
(.074)\end{array}$ & $\begin{array}{l}.278 \\
(.067)\end{array}$ & $\begin{array}{l}.187 \\
(.053)\end{array}$ \\
\hline $\mathrm{yr}=1982$ & $\begin{array}{l}.141 \\
(.022)\end{array}$ & $\begin{array}{l}-.079 \\
(.018)\end{array}$ & $\begin{array}{l}-.241 \\
(.012)\end{array}$ & $\begin{array}{l}.266 \\
(.044)\end{array}$ & $\begin{array}{l}-.071 \\
(.037)\end{array}$ & $\begin{array}{l}-.199 \\
(.030)\end{array}$ \\
\hline $\mathrm{yr}=1987$ & $\begin{array}{l}.026 \\
(.023)\end{array}$ & $\begin{array}{l}.005 \\
(.019)\end{array}$ & $\begin{array}{l}-.220 \\
(.012)\end{array}$ & $\begin{array}{l}.420 \\
(.042)\end{array}$ & $\begin{array}{l}.125 \\
(.034)\end{array}$ & $\begin{array}{l}-.042 \\
(.026)\end{array}$ \\
\hline $\mathrm{yr}=1992$ & $\begin{array}{l}-.015 \\
(.024)\end{array}$ & $\begin{array}{l}.153 \\
(.019)\end{array}$ & $\begin{array}{l}-.163 \\
(.012)\end{array}$ & $\begin{array}{c}.572 \\
(.041)\end{array}$ & $\begin{array}{l}.208 \\
(.032)\end{array}$ & $\begin{array}{l}-.020 \\
(.026)\end{array}$ \\
\hline $\mathrm{yr}=1997$ & $\begin{array}{l}-.132 \\
(.026)\end{array}$ & $\begin{array}{l}.253 \\
(.024)\end{array}$ & $\begin{array}{l}-.140 \\
(.016)\end{array}$ & $\begin{array}{l}.597 \\
(.044)\end{array}$ & $\begin{array}{l}.082 \\
(.035)\end{array}$ & $\begin{array}{l}-.106 \\
(.028)\end{array}$ \\
\hline alpha & $\begin{array}{l}.054 \\
(.004)\end{array}$ & & & $\begin{array}{l}.017 \\
(.012)\end{array}$ & & \\
\hline $\mathrm{N}$ & 3762 & 3740 & 3739 & 3762 & 3052 & 3052 \\
\hline R-square & .189 & .299 & .212 & .145 & .113 & .066 \\
\hline
\end{tabular}

\footnotetext{
* Use negative binomial model for the number of firms. Remaining regressions are OLS
} 
Table 2. Models of the Number of Entrants and Exits (Negative Binomial)

\begin{tabular}{|c|c|c|c|c|c|c|c|c|}
\hline & \multicolumn{4}{|c|}{ Dentists } & \multicolumn{4}{|c|}{ Chiropractors } \\
\hline & Entry & Entry & Exit & Exit & Entry & Entry & Exit & Exit \\
\hline Constant & $\begin{array}{c}-6.331 \\
(1.120)\end{array}$ & $\begin{array}{l}-2.019 \\
(.869)\end{array}$ & $\begin{array}{c}-7.678 \\
(.905)\end{array}$ & $\begin{array}{c}-3.112 \\
(.769)\end{array}$ & $\begin{array}{c}-9.388 \\
(1.179)\end{array}$ & $\begin{array}{l}-4.144 \\
(1.038)\end{array}$ & $\begin{array}{c}-5.403 \\
(1.674)\end{array}$ & $\begin{array}{c}2.711 \\
(1.301)\end{array}$ \\
\hline Log Market Population & $\begin{array}{c}.839 \\
(.027)\end{array}$ & $\begin{array}{c}.338 \\
(.032)\end{array}$ & $\begin{array}{c}.847 \\
(.025)\end{array}$ & $\begin{array}{c}.300 \\
(.031)\end{array}$ & $\begin{array}{c}.684 \\
(.032)\end{array}$ & $\begin{array}{c}.295 \\
(.043)\end{array}$ & $\begin{array}{c}.510 \\
(.044)\end{array}$ & $\begin{array}{c}.106 \\
(.044)\end{array}$ \\
\hline Log Per-capita Income & $\begin{array}{c}.336 \\
(.120)\end{array}$ & $\begin{array}{c}.069 \\
(.094)\end{array}$ & $\begin{array}{c}.487 \\
(.099)\end{array}$ & $\begin{array}{c}.208 \\
(.083)\end{array}$ & $\begin{array}{c}.700 \\
(.131)\end{array}$ & $\begin{array}{c}.233 \\
(.118)\end{array}$ & $\begin{array}{c}.309 \\
(.186)\end{array}$ & $\begin{array}{c}-.428 \\
(.143)\end{array}$ \\
\hline Log Market Wage & $\begin{array}{c}.925 \\
(.090)\end{array}$ & $\begin{array}{c}.408 \\
(.077)\end{array}$ & $\begin{array}{c}.698 \\
(.087)\end{array}$ & $\begin{array}{c}.209 \\
(.081)\end{array}$ & $\begin{array}{c}.416 \\
(.116)\end{array}$ & $\begin{array}{c}.120 \\
(.110)\end{array}$ & $\begin{array}{c}.310 \\
(.163)\end{array}$ & $\begin{array}{c}.011 \\
(.134)\end{array}$ \\
\hline $\mathrm{yr}=1982$ & $\begin{array}{c}-.344 \\
(.040)\end{array}$ & $\begin{array}{l}-.307 \\
(.035)\end{array}$ & $\begin{array}{c}.024 \\
(.042)\end{array}$ & $\begin{array}{c}-.057 \\
(.039)\end{array}$ & $\begin{array}{l}.205 \\
(.058)\end{array}$ & $\begin{array}{c}.274 \\
(.061)\end{array}$ & $\begin{array}{l}-.073 \\
(.077)\end{array}$ & $\begin{array}{l}-.178 \\
(.071)\end{array}$ \\
\hline $\mathrm{yr}=1987$ & $\begin{array}{c}-.723 \\
(.043)\end{array}$ & $\begin{array}{c}-.578 \\
(.038)\end{array}$ & $\begin{array}{l}-.214 \\
(.043)\end{array}$ & $\begin{array}{c}-.218 \\
(.040)\end{array}$ & $\begin{array}{c}.090 \\
(.059)\end{array}$ & $\begin{array}{c}.324 \\
(.061)\end{array}$ & $\begin{array}{l}-.130 \\
(.079)\end{array}$ & $\begin{array}{l}-.240 \\
(.073)\end{array}$ \\
\hline $\mathrm{yr}=1992$ & $\begin{array}{c}-.689 \\
(.048)\end{array}$ & $\begin{array}{c}-.535 \\
(.040)\end{array}$ & $\begin{array}{c}-.260 \\
(.049)\end{array}$ & $\begin{array}{c}-.250 \\
(.042)\end{array}$ & $\begin{array}{l}.124 \\
(.065)\end{array}$ & $\begin{array}{c}.475 \\
(.069)\end{array}$ & $\begin{array}{l}.185 \\
(.075)\end{array}$ & $\begin{array}{c}-.051 \\
(.072)\end{array}$ \\
\hline $\mathrm{yr}=1997$ & $\begin{array}{c}-.751 \\
(.053)\end{array}$ & $\begin{array}{l}-.490 \\
(.045)\end{array}$ & $\begin{array}{l}-.234 \\
(.049)\end{array}$ & $\begin{array}{l}-.149 \\
(.044)\end{array}$ & $\begin{array}{c}.183 \\
(.063)\end{array}$ & $\begin{array}{c}.657 \\
(.069)\end{array}$ & $\begin{array}{c}.415 \\
(.081)\end{array}$ & $\begin{array}{c}.141 \\
(.079)\end{array}$ \\
\hline $\mathrm{N}(\mathrm{t})$ & & $\begin{array}{c}.007 \\
(.003)\end{array}$ & & $\begin{array}{c}.050 \\
(.003)\end{array}$ & & $\begin{array}{c}-.005 \\
(.011)\end{array}$ & & $\begin{array}{c}.211 \\
(.012)\end{array}$ \\
\hline $\begin{array}{l}\text { Potential Entrants } \\
\text { NPE(t) }\end{array}$ & & $\begin{array}{l}.043 \\
(.003)\end{array}$ & & $\begin{array}{l}.004 \\
(.002)\end{array}$ & & $\begin{array}{l}.115 \\
(.010)\end{array}$ & & $\begin{array}{l}.004 \\
(.007)\end{array}$ \\
\hline alpha & $\begin{array}{l}.187 \\
(.018)\end{array}$ & $\begin{array}{l}.062 \\
(.010)\end{array}$ & $\begin{array}{l}.090 \\
(.014)\end{array}$ & $\begin{array}{l}.005 \\
(.009)\end{array}$ & $\begin{array}{l}.164 \\
(.035)\end{array}$ & $\begin{array}{l}.088 \\
(.022)\end{array}$ & $\begin{array}{l}.119 \\
(.057)\end{array}$ & $\begin{array}{l}.004 \\
(.015)\end{array}$ \\
\hline $\mathrm{N}$ & 3762 & 3762 & 3740 & 3740 & 3762 & 3762 & 3052 & 3052 \\
\hline R-square & .128 & .189 & .130 & .176 & .080 & .148 & .053 & .134 \\
\hline
\end{tabular}


Table 3. Results for Market Structure Regressions with History Variables

\begin{tabular}{|c|c|c|c|c|c|c|}
\hline & \multicolumn{3}{|c|}{ Dentists } & \multicolumn{3}{|c|}{ Chiropractors } \\
\hline & $\begin{array}{l}\text { Number of } \\
\text { Firms * }\end{array}$ & $\begin{array}{l}\text { Log Average } \\
\text { Revenue }\end{array}$ & $\begin{array}{l}\text { Log Labor } \\
\text { Productivity }\end{array}$ & $\begin{array}{l}\text { Number of } \\
\text { Firms * }\end{array}$ & $\begin{array}{l}\text { Log Average } \\
\text { Revenue }\end{array}$ & $\begin{array}{l}\text { Log Labor } \\
\text { Productivity }\end{array}$ \\
\hline Constant & $\begin{array}{l}-.928 \\
(.365)\end{array}$ & $\begin{array}{l}1.313 \\
(.389)\end{array}$ & $\begin{array}{l}1.871 \\
(.249)\end{array}$ & $\begin{array}{l}-4.049 \\
(.719)\end{array}$ & $\begin{array}{l}.807 \\
(.786)\end{array}$ & $\begin{array}{l}1.482 \\
(.578)\end{array}$ \\
\hline Log Market Population & $\begin{array}{l}.316 \\
(.017)\end{array}$ & $\begin{array}{c}.074 \\
(.018)\end{array}$ & $\begin{array}{c}.033 \\
(.012)\end{array}$ & $\begin{array}{l}.296 \\
(.030)\end{array}$ & $\begin{array}{l}.092 \\
(.026)\end{array}$ & $\begin{array}{l}.065 \\
(.020)\end{array}$ \\
\hline Log Per-capita Income & $\begin{array}{l}.119 \\
(.039)\end{array}$ & $\begin{array}{l}.286 \\
(.042)\end{array}$ & $\begin{array}{l}.115 \\
(.027)\end{array}$ & $\begin{array}{l}.378 \\
(.079)\end{array}$ & $\begin{array}{c}.278 \\
(.086)\end{array}$ & $\begin{array}{l}.119 \\
(.063)\end{array}$ \\
\hline Log Market Wage & $\begin{array}{l}.305 \\
(.039)\end{array}$ & $\begin{array}{l}.298 \\
(.038)\end{array}$ & $\begin{array}{l}.157 \\
(.025)\end{array}$ & $\begin{array}{l}-.046 \\
(.067)\end{array}$ & $\begin{array}{l}.317 \\
(.070)\end{array}$ & $\begin{array}{l}.212 \\
(.054)\end{array}$ \\
\hline $\mathrm{yr}=1987$ & $\begin{array}{l}-.089 \\
(.017)\end{array}$ & $\begin{array}{l}.103 \\
(.018)\end{array}$ & $\begin{array}{l}.035 \\
(.011)\end{array}$ & $\begin{array}{l}.173 \\
(.033)\end{array}$ & $\begin{array}{l}.188 \\
(.040)\end{array}$ & $\begin{array}{l}.152 \\
(.030)\end{array}$ \\
\hline $\mathrm{yr}=1992$ & $\begin{array}{l}-.116 \\
(.018)\end{array}$ & $\begin{array}{l}.251 \\
(.019)\end{array}$ & $\begin{array}{c}.092 \\
(.012)\end{array}$ & $\begin{array}{l}.270 \\
(.035)\end{array}$ & $\begin{array}{l}.239 \\
(.041)\end{array}$ & $\begin{array}{l}.173 \\
(.031)\end{array}$ \\
\hline $\mathrm{yr}=1997$ & $\begin{array}{l}-.153 \\
(.021)\end{array}$ & $\begin{array}{l}.366 \\
(.022)\end{array}$ & $\begin{array}{l}.124 \\
(.014)\end{array}$ & $\begin{array}{l}.266 \\
(.038)\end{array}$ & $\begin{array}{l}.119 \\
(.044)\end{array}$ & $\begin{array}{l}.109 \\
(.034)\end{array}$ \\
\hline $\mathrm{N}(\mathrm{t}-1)$ & $\begin{array}{c}.042 \\
(.002)\end{array}$ & $\begin{array}{l}-.014 \\
(.013)\end{array}$ & $\begin{array}{c}-.009 \\
(.012)\end{array}$ & $\begin{array}{c}.155 \\
(.013)\end{array}$ & $\begin{array}{c}.063 \\
(.023)\end{array}$ & $\begin{array}{l}-.003 \\
(.018)\end{array}$ \\
\hline $\begin{array}{l}\text { Potential Entrants } \\
\text { NPE (t-1) }\end{array}$ & $\begin{array}{l}.008 \\
(.001)\end{array}$ & $\begin{array}{l}.057 \\
(.013)\end{array}$ & $\begin{array}{c}.034 \\
(.008)\end{array}$ & $\begin{array}{l}.032 \\
(.005)\end{array}$ & $\begin{array}{c}.021 \\
(.019)\end{array}$ & $\begin{array}{l}.033 \\
(.015)\end{array}$ \\
\hline alpha & .000 & & & $\begin{array}{l}.012 \\
(.009)\end{array}$ & & \\
\hline $\mathrm{N}$ & 3010 & 2945 & 2945 & 3010 & 2147 & 2144 \\
\hline R-square & .282 & .326 & .183 & .222 & .104 & .072 \\
\hline
\end{tabular}

* Use negative binomial model for the number of firms. Remaining regressions are OLS 
Figure 1: Cumulative Distribution of the Number of Dentists and Chiropractors in Local Markets

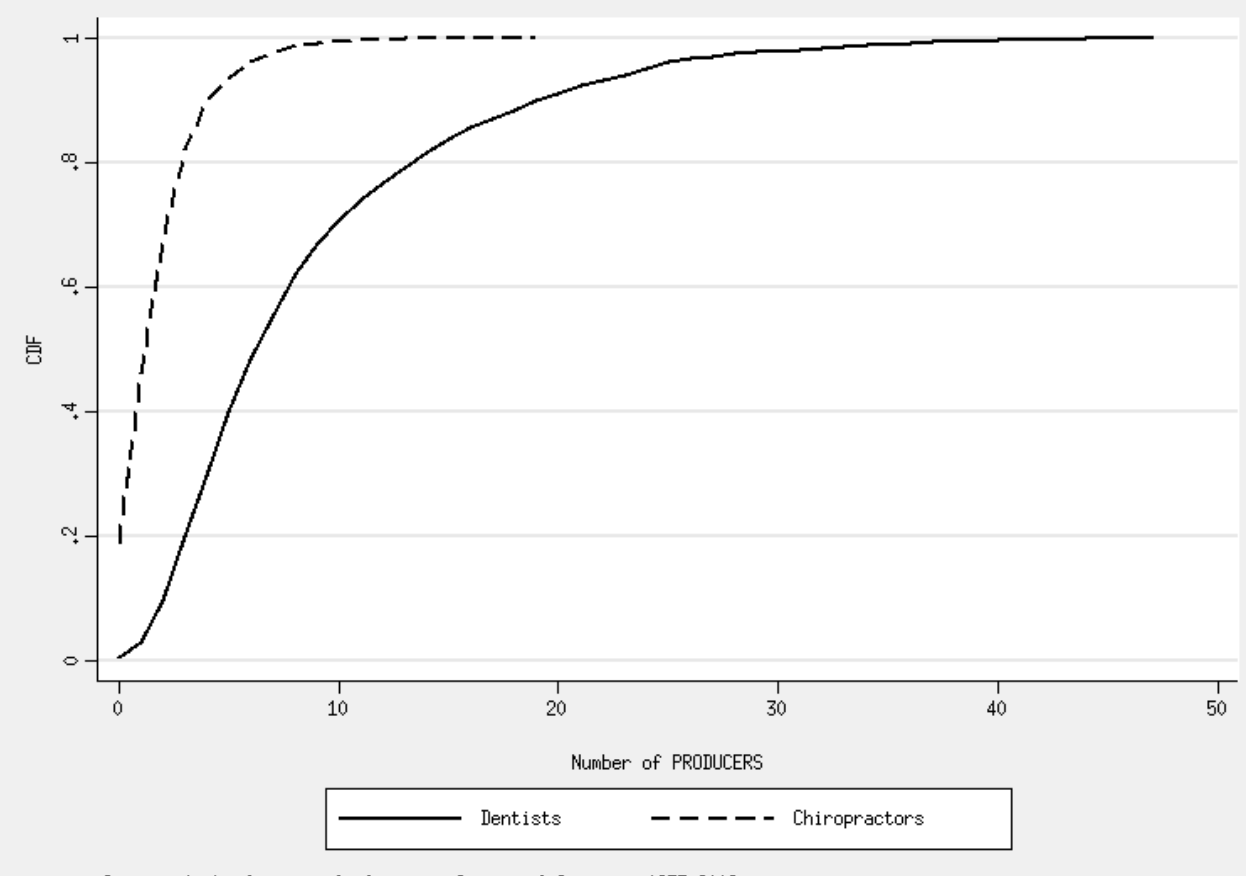

Source: Author's own calculations, Census of Services 1977-2002

Figure 2: Cumulative Distribution of the Number of Entering Dentists and Chiropractors in Local Markets

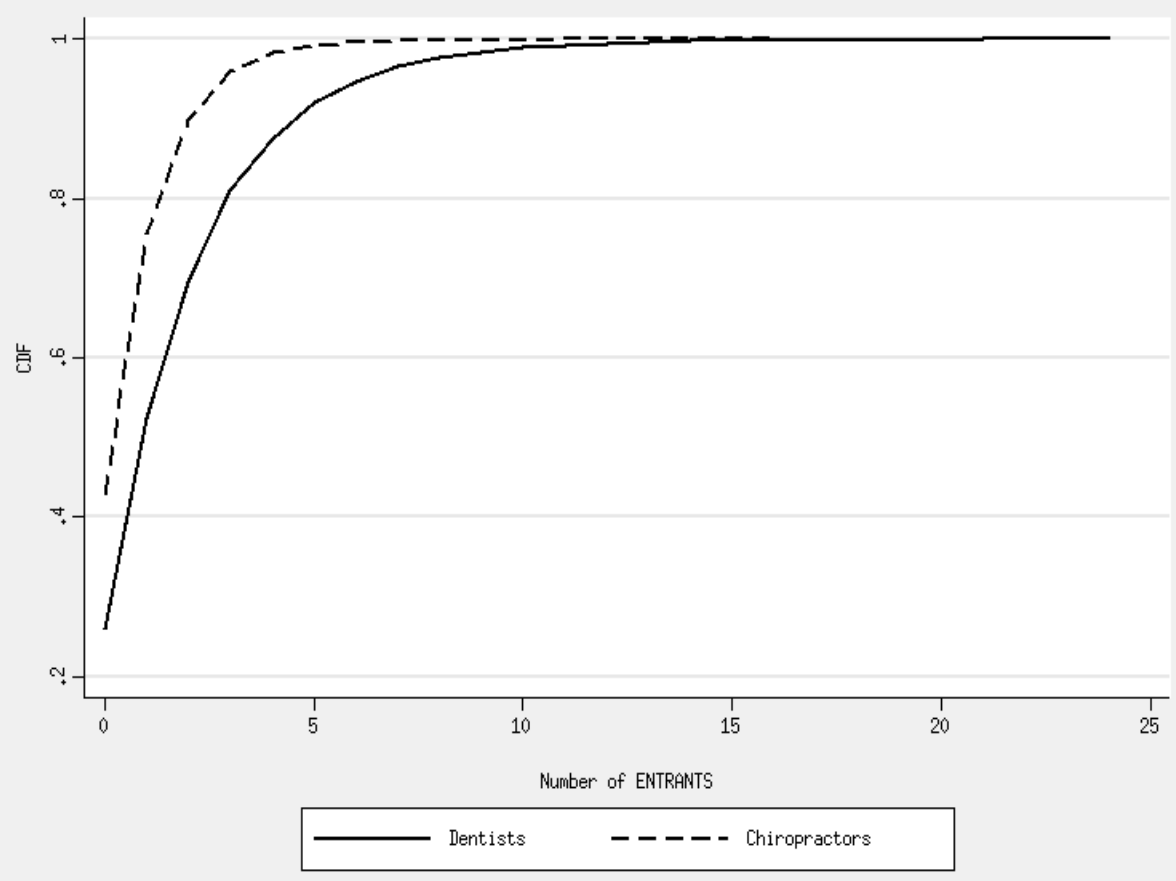

Source: Author's own calculations, Census of Services 1977-2002 
Figure 3: Cumulative Distribution of the Number of Exiting Dentists and Chiropractors in Local Markets

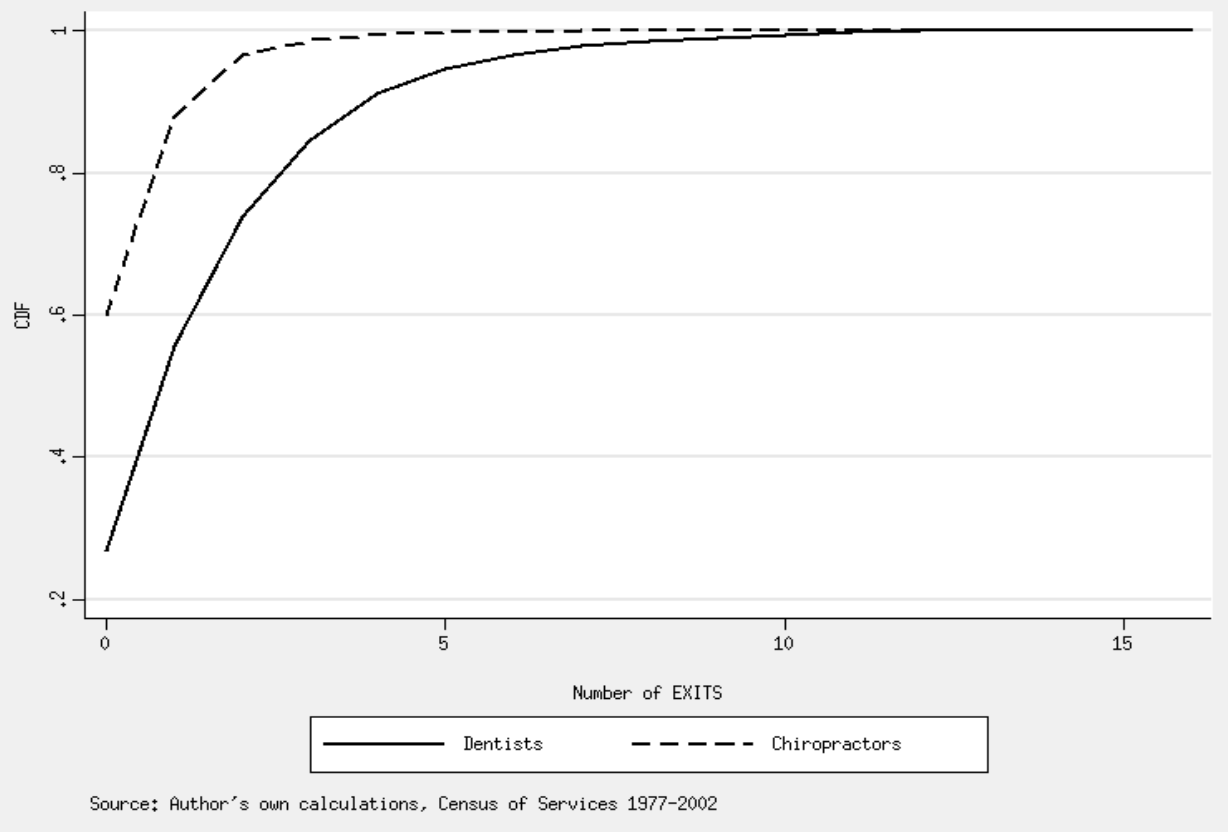

Figure 4: Number of Producers by Market Size

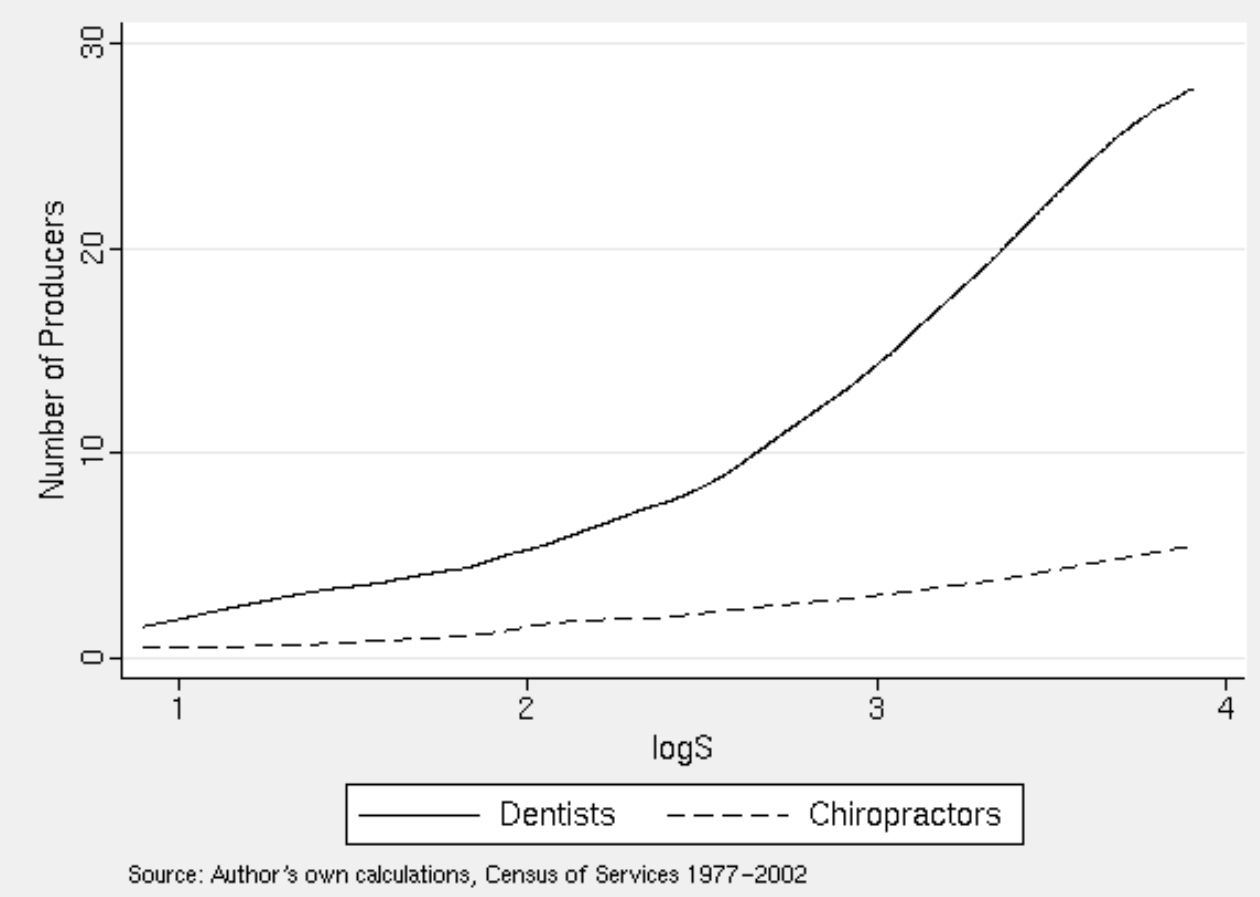


Figure 5: Number of Entrants by Market Size

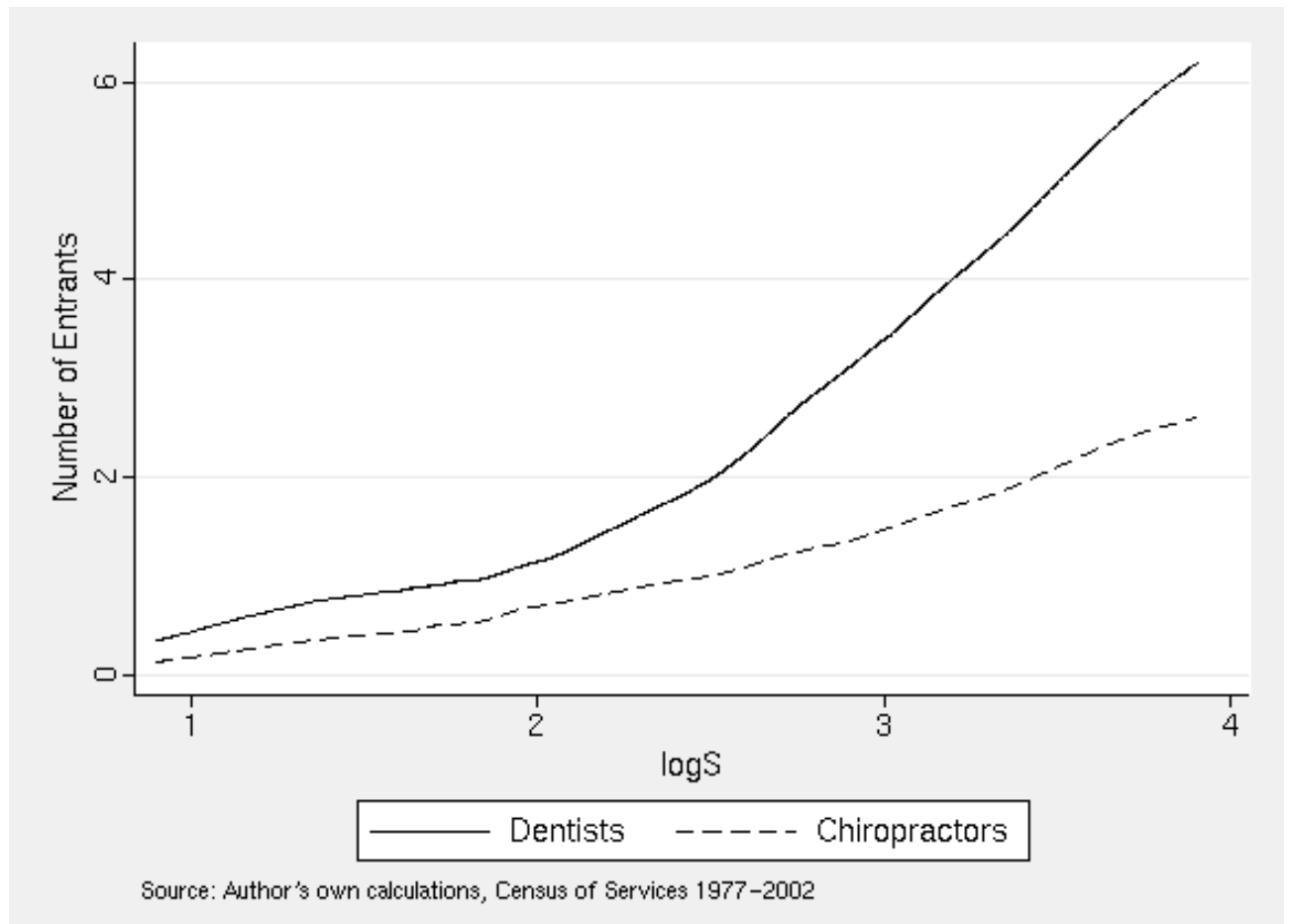

Figure 6: Number of Exits by Market Size

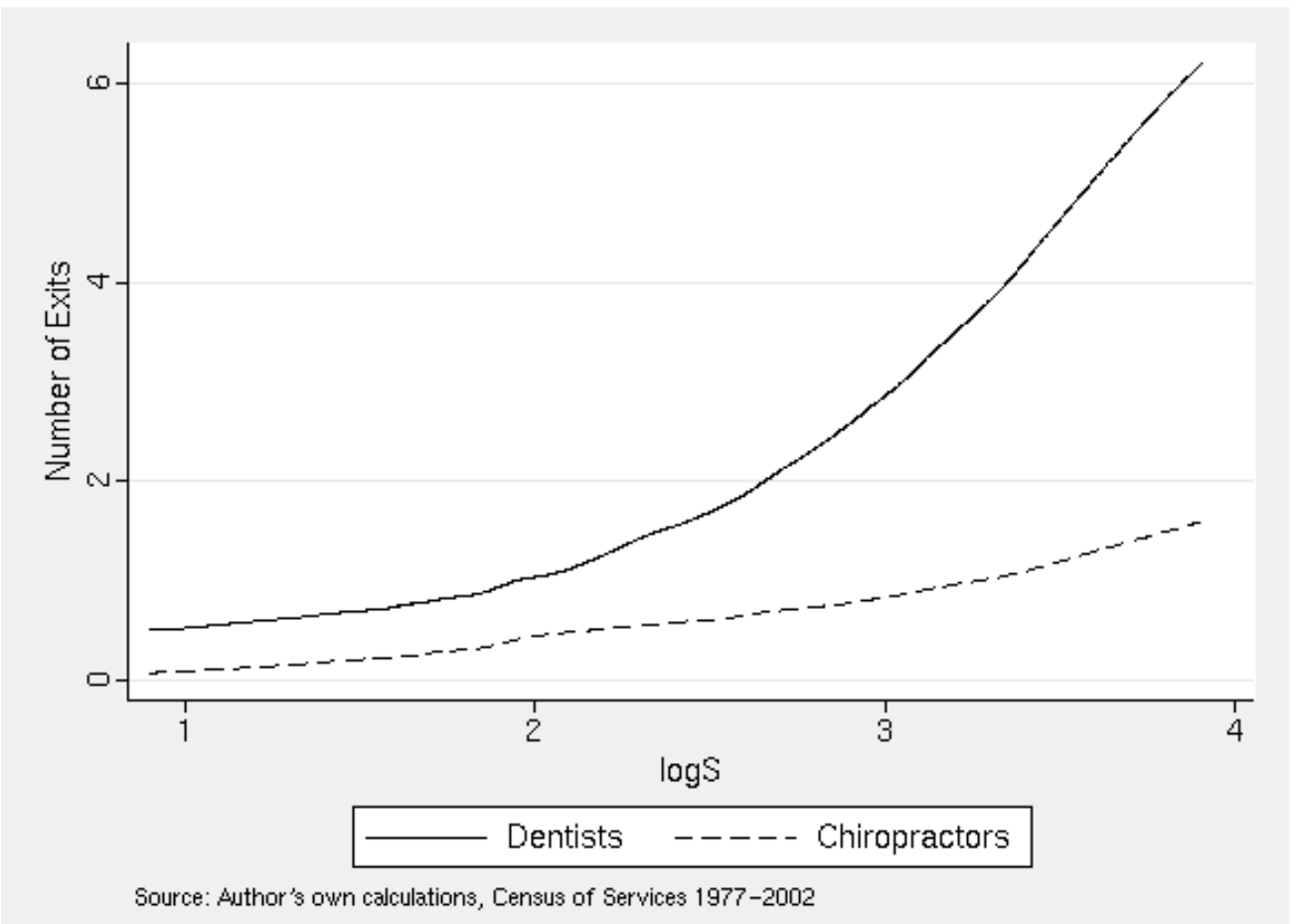


Figure 7: Log of Population-per-Producer by Market Size

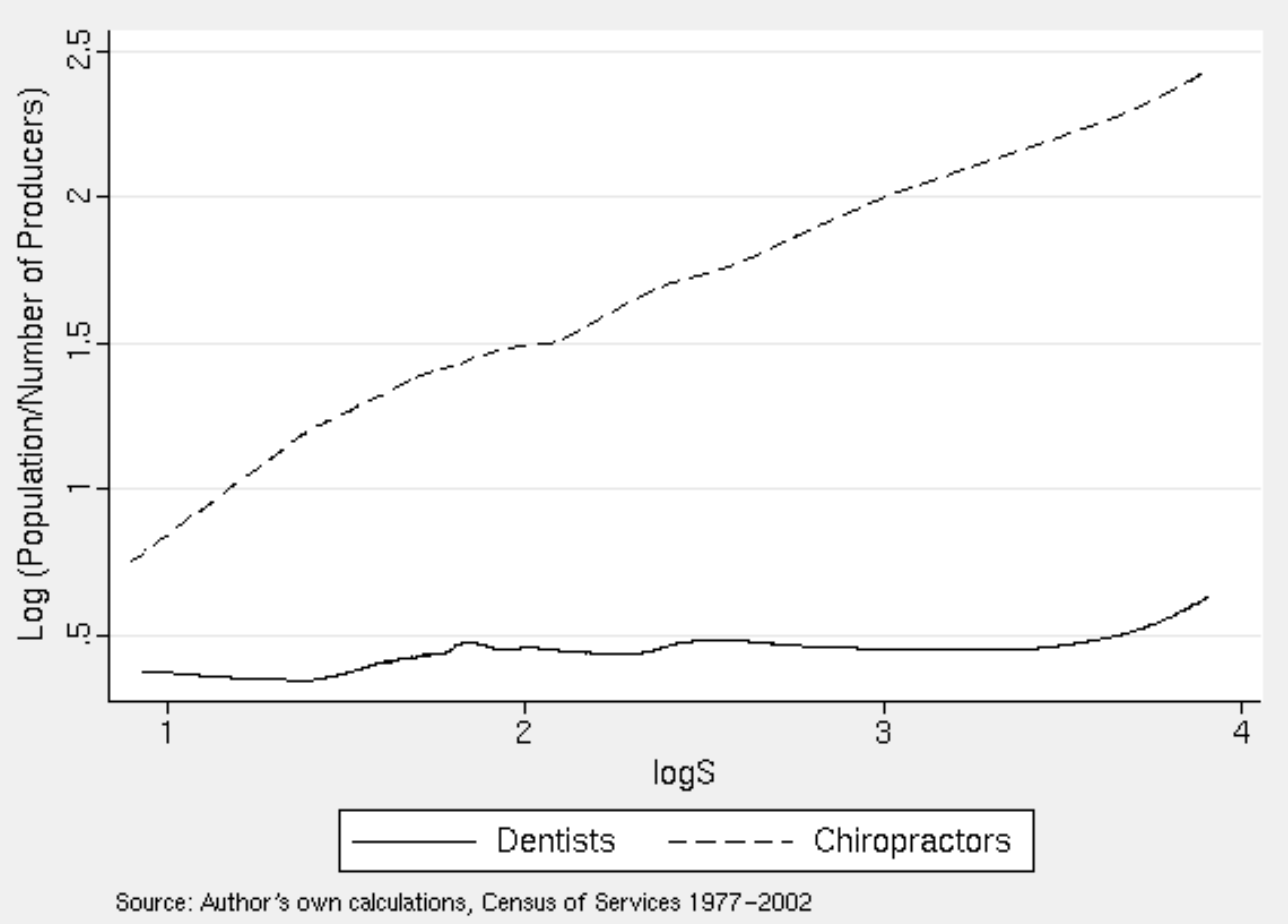


Figure 8: Log of Average Revenue per Producer by Market Size

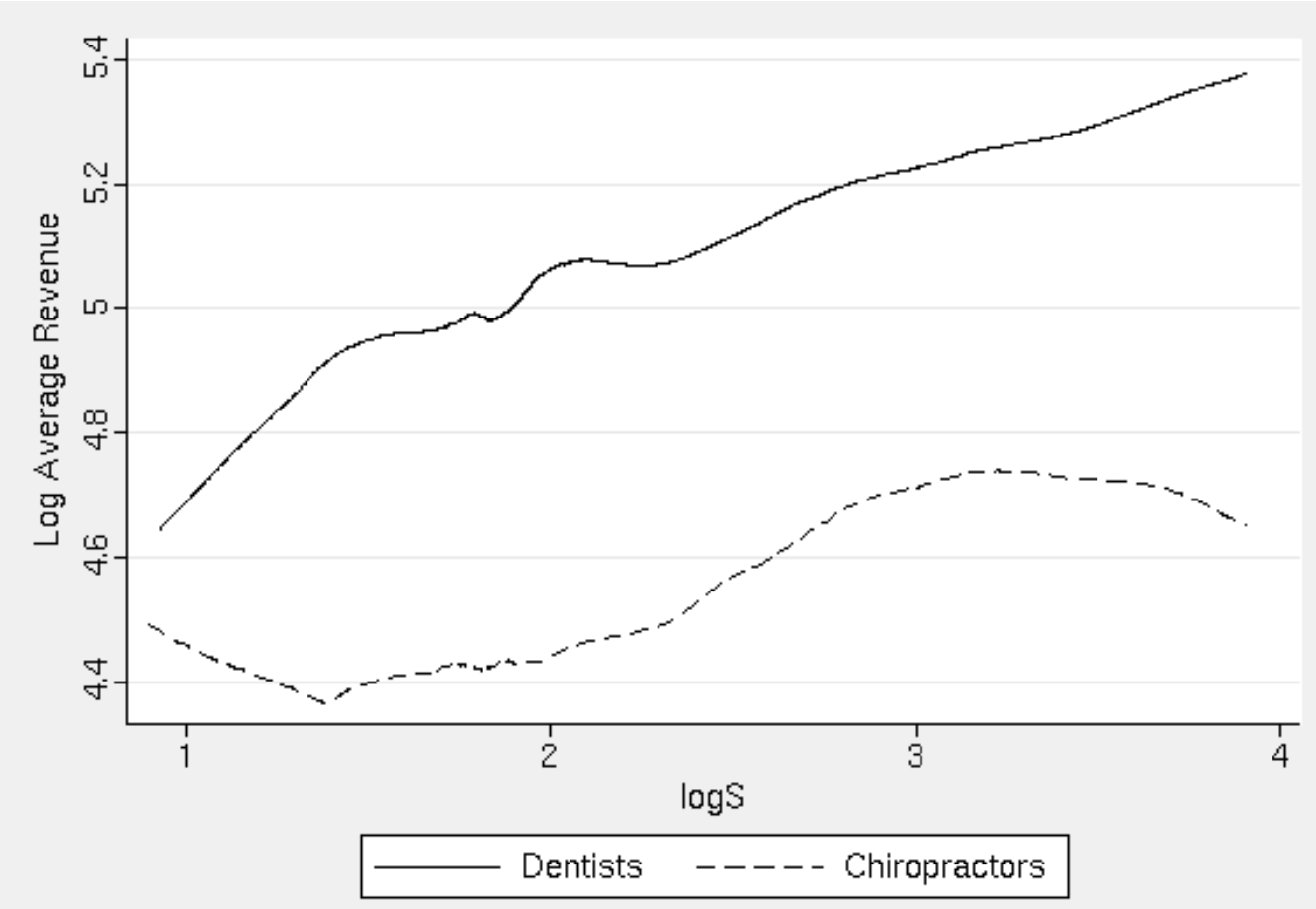

Source: Author's own calculations, Census of Services 1977-2002

Figure 9: Log of Average Labor Productivity

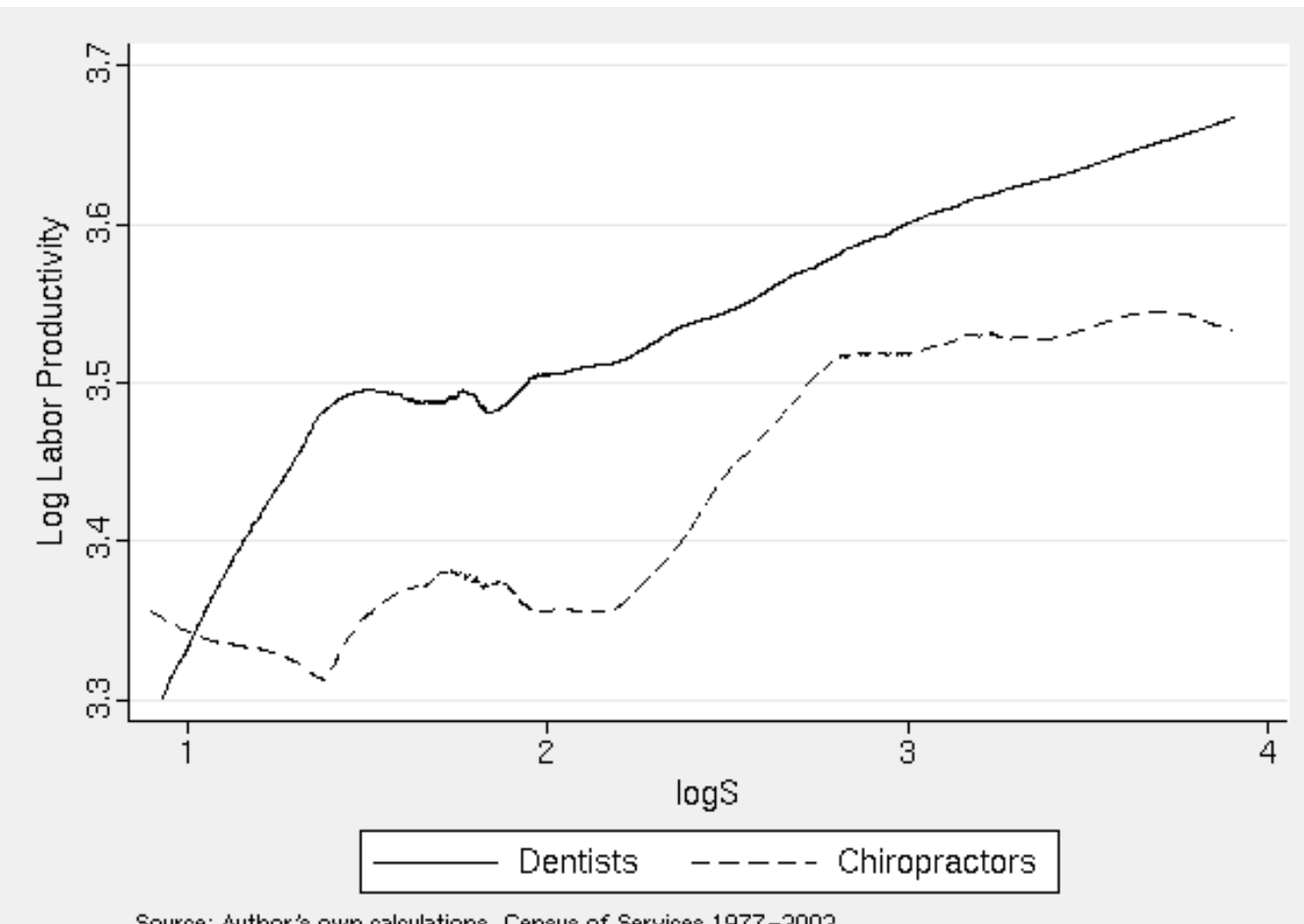

Source: Author's own calculations, Census of Services 1977-2002 